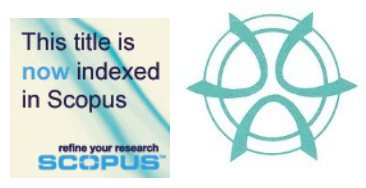

PLANNING MALAYSIA:

Journal of the Malaysian Institute of Planners

VOLUME 19 ISSUE 4 (2021), Page 231 - 243

\title{
THE FACTORS AFFECTING THE WELFARE OF STREET VENDORS IN INDONESIA
}

\author{
Eko Handoyo ${ }^{1}$, Tutik Wijayanti ${ }^{2}$ \\ ${ }^{1,2}$ Faculty of Social Sciences \\ UNIVERSITAS NEGERI SEMARANG
}

\begin{abstract}
This study aimed to examine how the welfare of street vendors is influenced by education, financial capital, geographical distance, and social networks. A mixedmethod approach that combines both quantitative and qualitative methods was used. The results showed that the welfare of street vendors is at a low level and is simultaneously influenced by education, financial capital, geographical distance, and social networks with a determination value of r-square (r2) of 0.783 or $78.3 \%$. However, there is a need for further and in-depth studies on the influence of geographical factors and social networks on the welfare of street vendors, especially on geographical factors with a significant influence on welfare.
\end{abstract}

Keywords: Geographical Distance; Social Networks; Welfare; Financial Capital; Street Vendors; Education

\footnotetext{
${ }^{1}$ Associate Professor at Universitas Negeri Semarang. Email: eko.handoyo@mail.unnes.ac.id
} 
Eko Handoyo, Tutik Wijayanti

The Factors Affecting the Welfare of Street Vendors in Indonesia

\section{INTRODUCTION}

The informal sector has a significant contribution to the economic order, though its businesses are not officially registered, irregular, and poorly organized (Rothenberg et al., 2016; Stuart et al., 2018). Since the activities of this sector are not recorded in the official government statistics or covered by state regulations and taxes, it refers to a shadow economy (Horn, 2018; Mróz, 2018; Rei, 2008). Furthermore, it is also referred to as the underground economy because it is characterized by limited legal activities (Feige, 1990; Losby et al., 2002; Petrova, 2018). The informal sector comprises people with a low level of education, invalid business license, no specific hours for operating, inappropriately organized, and poor business actors (Charmes, 2012; Mitullah, 2003; Mukherjee, 2016; Portes et al., 1989; Stuart et al., 2018).

Although the shadow economy is a source of livelihoods to millions of people and represents a "safety net" for most poor individuals and families, the adverse effects on the economy and society significantly exceed its positive impact (Camacho et al., 2017; Golubovic \& Dzunic, 2015). However, it can provide a sustainable livelihood for urban communities when appropriately managed (Ruzek, 2015).

The shadow economy has a significant link to the formal sector. For instance, it helps in marketing the formal economy's products and sells daily household items, such as school supplies, cosmetics, and drinking water (Bromley, 1978; Khasnobis et al., 2006). The supply and marketing chain stimulates economic growth in urban areas, though the role of Street Vendors is not recognized.

A street vendor is an entrepreneur with sufficient capital for production activities and offers goods for sale to the public without a permanent built-up structure for transactions. Street vendors are often stationary and occupy spaces on the pavements or other public and private spaces. Furthermore, they may be mobile and move to different places, carrying their wares on pushcarts or baskets (Bhowmik, 2005). They participate in the production and selling of goods and services to fulfil the needs of consumers. However, the respective activities occur in places that are strategic, economic, and informal environments.

Like other big cities in Indonesia, Semarang faces the problem of urbanization, including many street vendors. They are very observant in utilizing the remaining public spaces, such as the sidewalk and a small road shoulder. Furthermore, the vendors are good at exploiting opportunities and often consider the strategic locations between residential and educational place. This has made them creative in utilizing spaces for their activities or hawking wares.

According to previous studies, educational background, financial capital, geographical distance, and social networks significantly influence the overall welfare of street vendors, including income (Anggraini, 2019; Harahap, 2017; Ifotania, 2010; Nurbaiti \& Chotib, 2020; Setyaningsih et al., 2019). 
Geographically, small business economic actors operate in urban centers with high economic value (Utomo et al., 2018).

This study conceptually examines the welfare of street vendors comprehensively. It has a novelty on street vendors since geographical and social network factors have not been used as a variable to examine welfare in Semarang. Specifically, this study examines the following problems:

(1) The welfare of street vendors in Semarang.

(2) The influence of education, financial capital, geographical distance, and social networks on the street vendors' welfare in Semarang.

\section{LITERATURE REVIEW}

Urbanization affects urban economic development (Rakhmatulloh et al., 2018). For instance, it has led to various informal sectors in Semarang city, with most immigrants selling food. The street vendors who sell food are called culinary street vendors and are found throughout Semarang. The rapid development of this metropolitan city has attracted street vendors currently scattered in the subdistricts. Both organized and unorganized street vendors occupy the public spaces. In general, the number of unorganized vendors surpasses the organized. According to Syariffuddin et al. (2017), 78\% of vendors in Semarang are unorganized, and their number has significantly increased in the last ten years. Mobile street vendors usually use cars and three-wheeled or two-wheeled motorbikes found throughout the city. Essentially, they are significantly increasing due to their high mobility and can be found on the roadsides in almost all public spaces. They sell different kinds of vegetables, bread, snacks, drinks, fruits, rice, cooking oil, spices, other household necessities, clothes, credit for cellphones, motorcycle tires, satellite dishes, and plants.

Welfare is the goal pursued by street vendors, though difficult to achieve. It is significantly affected by various factors, including education, geographical distance, business capital, and social capital. Furthermore, it is affected by government policies or districts because of operating in the public spaces (Bromley, 2000). It is vital to examine the link between government policy and the welfare of street vendors, focusing on the concept of a prosperous country. This concept clarifies the kind of welfare state model that the Indonesian government implemented. The policies on survival and the welfare of street vendors are influenced by what the government considers. There are many approaches, paradigms, and welfare models applied by the government to organize people's lives.

The basic idea of the welfare state model comes from the strategy of managing resources for the welfare of the people and includes the liberal, corporatist, and democratic aspects (Andersen, 2012). The United States adopts the liberal welfare state model to formulate policies that allow people to obtain social insurance benefits, establish social safety nets, and care for the poor. 
Eko Handoyo, Tutik Wijayanti

The Factors Affecting the Welfare of Street Vendors in Indonesia

Moreover, this model was adopted by Germany to provide social insurance benefits to the public concerning work and income. In Sweden, it stipulates that social assistance is the mutual responsibility of both citizens and the state.

The government can improve the welfare of the people through social policies. Social welfare is conceived in three elements: how social problems are managed, needs to be met, and opportunities for advancement (Midgley, 1999). These three elements apply to individuals, families, groups, and communities.

The government is responsible for increasing income through investments both in the country and abroad. In general, investments, such as banking, property, hotels, agriculture, plantations, marine, trade, and oil and gas, are in the formal sector. The need for rapid economic growth is the main reason the government policies focus more on developing the formal economic sector.

The informal economic sector, which includes the small or retail trade like food and beverage, has not received much attention from the central and regional governments. However, the publication of the Presidential Regulation (Perpres) No. 125/ 2012 regarding the Coordination of Structuring and Empowerment of Street Vendors affects the future of street vendors. The Home Affairs Ministry Regulation (Permendagri) No. 41/ 2012 regarding the Guidelines for Structuring and Empowering of Street Vendors has also shifted government attention to registered or official street vendors than the unregistered ones. Nilakusmawati, D. P. E., Susilawati, M., \& Wall, G. (2019) stated "the policy of empowerment of the program of street vendors by the government is not optimal". This is indicated by the number of unregistered vendors relocated or evicted from their selling places.

Social policies related to social welfare services should guarantee rights to all citizens, including the welfare of the street vendors. Therefore, the policies taken are not partially organized but comprehensively and empower street vendors by involving the state and society. They activate social welfare institutions by following the basis of the state philosophy, Pancasila.

Mostly, the previous studies focused on the influence of education, financial capital, geographic distance, and social networks on business success, also street vendors' welfare. These include knowledge and education influence on the success of informal sector traders (Karondo \& Tumaini, 2021; Nirathron, 2006a). The effects of financial capital on the business continuity of street vendors (Gatere, 2016; Marliati, 2020), and the use of public space (geographic factors), and the survival of street vendors (Winter, 2017). In general, food vendors mostly sell near housing, transportation hubs, and workplaces (Rosales Chavez et al., 2021). Social networks also play an important role in determining the success and welfare of street vendors (El-Azzazy, 2019; Kebede, 2015; Mramba, 2015). Although several studies have been conducted on the welfare of street vendors (Giraldo et al., 2020; Nilakusmawati, D. P. E., Susilawati, M., \& Wall, 2019), most of them did not focus on essential variables, such as education, 
capital, and social networks. Specifically, they mainly focused on the partial relationship between variables. This study bridges the existing gap by focusing on education, financial capital, geographical distance, and social networks, the variables that influence the welfare of street vendors.

\section{RESEARCH METHOD}

This study used a sequential exploratory design and mixed methods that combine quantitative and qualitative to obtain complete, valid, reliable, and objective data (Creswell, 2014). A qualitative approach was used to describe the welfare of street vendors in Semarang (RQ1). In contrast, the effect of education, financial capital, geographical distance, and social network on the welfare of street vendors in Semarang (RQ2) was examined quantitatively. The unit of analysis is the street vendors trading in 13 study locations, as shown in Figure 1.

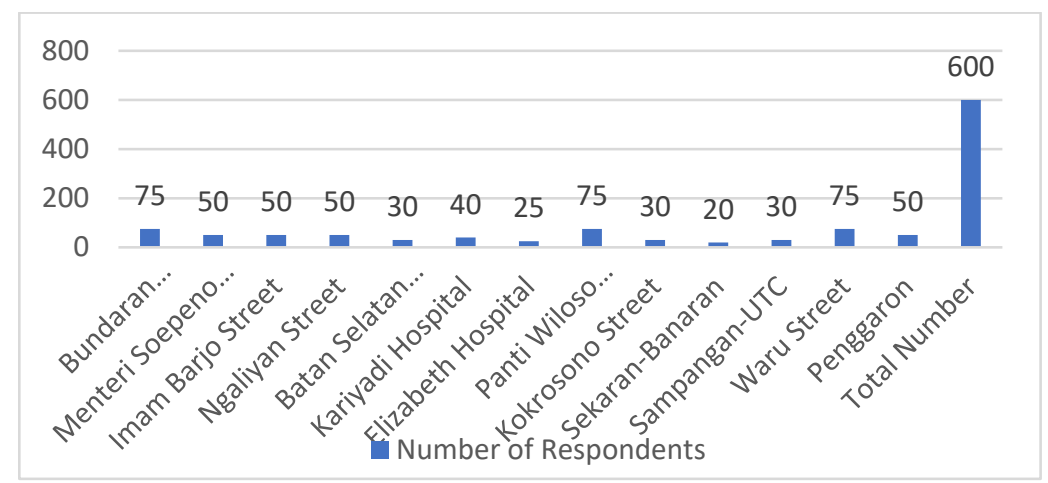

Figure 1. Distribution of Research Analysis Units

The sample was selected randomly by examining the proportion of the study location. A sample of 598 (rounded up to 600) was obtained from a population of 6000 with an error level of $1 \%$. This included the Culinary and Non-Culinary Street vendors who traded in the respective locations for at least 1 year. Furthermore, the 13 study locations were selected based on the number of streets vendors. The largest samples were taken at the Simpang Lima Roundabout, Kokrosono Street, and Waru Street.

Interviews and observation were used to collect qualitative data, while questionnaires were utilized to obtain quantitative data by giving respondents a set of questions or written statements. There was a questionnaire with five mains variables, including education, financial capital, geographical distance, and social networks as independent variables and the welfare of street vendors as the dependent variable. Moreover, the data validity test was conducted through informant reviews and triangulation of the sources. 
Eko Handoyo, Tutik Wijayanti

The Factors Affecting the Welfare of Street Vendors in Indonesia

The qualitative data analysis techniques were used to answer the first problem (RQ 1) and included data condensation, display, and drawing and verifying conclusions (Miles et al., 2014). Similarly, quantitative analysis techniques were used to answer the second problem (RQ 2) with independent and dependent variables. Specifically, the independent variables influence the dependent variable, including education, financial capital, geographical distance, and social networks symbolized as $\mathrm{X} 1, \mathrm{X} 2, \mathrm{X} 3$, and $\mathrm{X} 4$. Contrastingly, the dependent variable was the welfare of the street vendors, symbolized as $\mathrm{Y}$. The statistical analysis technique used was the multiple linear regression test. Before this test, linearity and significance were examined. The following formula was used to perform a multiple linear regression test.

$\mathrm{Y}=\alpha+\beta 1 \mathrm{X} 2+\beta 2 \mathrm{X} 2+\beta \mathrm{n} \mathrm{Xn}$

Description:

$\mathrm{Y}=$ Dependent variable or response.

$\mathrm{X}=$ Independent variable or predictor.

$\alpha=$ Constant.

$\beta=$ Slope or estimate coefficient.

Test rules significance:

a.F count $\geq F$ table with a significant level of $5 \%(0.05)$, then Ho is rejected.

b.F count $\leq \mathrm{F}$ table with a significant level of $5 \%(0.05)$, Ho is accepted.

In calculating the regression test, researchers used the help of the SPSS program.

\section{RESULTS}

\section{The Social Welfare of Street Vendors in Semarang}

The social welfare related to the street vendors is interpreted as a condition where life necessities are met, including clothing, shelter, food, health, and interacting with the environment to improve their living standards. Social welfare is examined based on several indicators, including assets owned, savings of money deposit institutions, such as banks and cooperatives, investment ownership like deposits, gold investment, property business, securities, and investing in cooperatives/CV/PT/other joint ventures. The results show that the assets owned by street vendors in Semarang are categorized as shown in Figure 2 below.

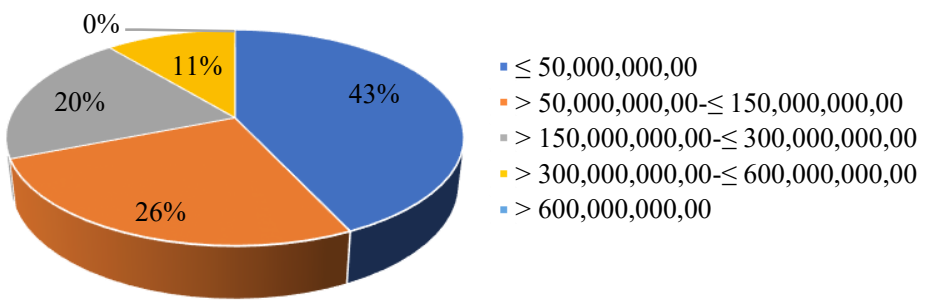

Property Owned (Rupiah)

Figure 2. The welfare of PKL in Semarang City based on Total Assets Owned Source: Primary Data Processed, 2020 
The street vendors in Semarang are classified into five main categories. The dominant category was for vendors with total assets of less than or equal to $(\leq)$ IDR 50,000,000.00, specifically 257 (43\%) respondents. Second, $158(26 \%)$ had total assets of $>$ IDR 50,000,000 - $\leq$ IDR 150,000,000.00. Third, $120(20 \%)$ had total assets of $>$ IDR $150,000,000.00$ - IDR 300,000,000.00. The fourth was a category had $65(11 \%)$ respondents with total assets worth >IDR $300,000,000.00-\leq$ IDR $600,000,000.00$. The las category had individuals with total assets worth more than (>) IDR 600,000,000.00.

The ownership of a certain amount of money saved in money-saving institutions, such as banks and cooperatives, was also used to examine the welfare of the vendors. In this regard, vendors were also divided into five distinct categories. The first had 238 respondents $(40 \%)$ without any savings, while the second one had $256(43 \%)$ with savings of less than or equal to $(\leq)$ IDR $10,000,000$. The third category had savings of $>$ IDR $10,000,000.00-\leq$ IDR $30,000,000.00$, specifically $69(12 \%)$. The fourth one had $14(2 \%)$ respondents with savings of $>$ IDR $30,000,000.00-\leq$ IDR $50,000,000.00$. The fifth category had $23(4 \%)$ vendors with savings of more than (>) IDR 50,000,000.00.

The ownership of investments such as deposits, gold investment, property business, securities, stock investment in cooperatives/CV/PT/other joint ventures was also considered. A total of 547 respondents (91\%) did not have any investment in the form of deposits, gold investment, property business, or other forms. Only $53(9 \%)$ had 1 type of investment.

Based on the indicators of assets, total savings, and investment, street vendors had a low level of welfare. The data obtained showed that $43 \%$ had total assets less than or equal to $(\leq)$ IDR $50,000,000$, while $40 \%$ had no savings. Furthermore, $43 \%$ had savings of less than or equal to $(\leq)$ IDR $10,000,000$, while $91 \%$ did not have any investments in deposits, gold, property business, or other forms of property.

The Influence of Education, Financial Capital, Geographical Distance, and Social Networking on the Social Welfare of Street Vendors in Semarang The data obtained were analyzed using IBM SPSS data processing software, with the social network, geographical distance, education, and financial capital as independent variables. The dependent variable was the welfare of the street vendors.

The statistical data processing showed that the correlation value $(\mathrm{R})$ was 0.885 . This was the percentage of the influence of the independent variable on the dependent one, also called the coefficient of determination $\left(\mathrm{R}^{2}\right)$. Specifically, the coefficient of determination (R2) was 0.783 . This means that the independent variables, including social networks, geographical distance, education, and financial capital, influenced $78.3 \%$ of the dependent variable. The remaining 
Eko Handoyo, Tutik Wijayanti

The Factors Affecting the Welfare of Street Vendors in Indonesia

$21.8 \%$ was influenced by other factors outside the $\mathrm{X}$ variable to make the value of e to be $=100 \%-\mathrm{R} 2=100 \%-78.3 \%=21,8 \%$.

Table 1. Model Summary

\begin{tabular}{|l|cccc|}
\hline Model & R & R Square & $\begin{array}{c}\text { Adjusted R } \\
\text { Square }\end{array}$ & $\begin{array}{l}\text { Std. Error of } \\
\text { the Estimate }\end{array}$ \\
\hline 1 & $\begin{array}{l}.885^{\mathrm{a}} \\
\text { a. Predictors: }\end{array}$ & $\begin{array}{c}.783 \\
\text { (Constant), Social Network, Distance_Geography, Education, } \\
\text { Financial Capital }\end{array}$ & $\begin{array}{c}.782 \\
.4266\end{array}$ \\
\hline
\end{tabular}

The statistical calculations show that the calculated $F$ value was 536.678 , while the significance of probability was 0.00 , smaller than 0.050 . Therefore, education, financial capital, geographical distance, and social networks simultaneously influenced the welfare of street vendors.

From table 2 , the regression equation of $Y=\beta 0+\beta 1+\beta 2+\beta 3+\beta 4+$ $\varepsilon$ or $\mathrm{Y}=2.143+0.302 \mathrm{X} 1+0.229 \mathrm{X} 2+0.232 \mathrm{X} 3+0.075 \mathrm{X} 4+\mathrm{e}$ was obtained. There was a constant of 2.143 and 0.302 as the coefficient of the effect of education (X1) on the Street Vendors Welfare. Furthermore, the regression coefficient of the effect of financial capital (X2) on Street Vendors Welfare was 0.229 , while geographical distance (X3) on Street Vendors Welfare was 0.232. The influence of Social Networks (X4) on Street Vendors Welfare was 0.075.

Table 2. Coefficients

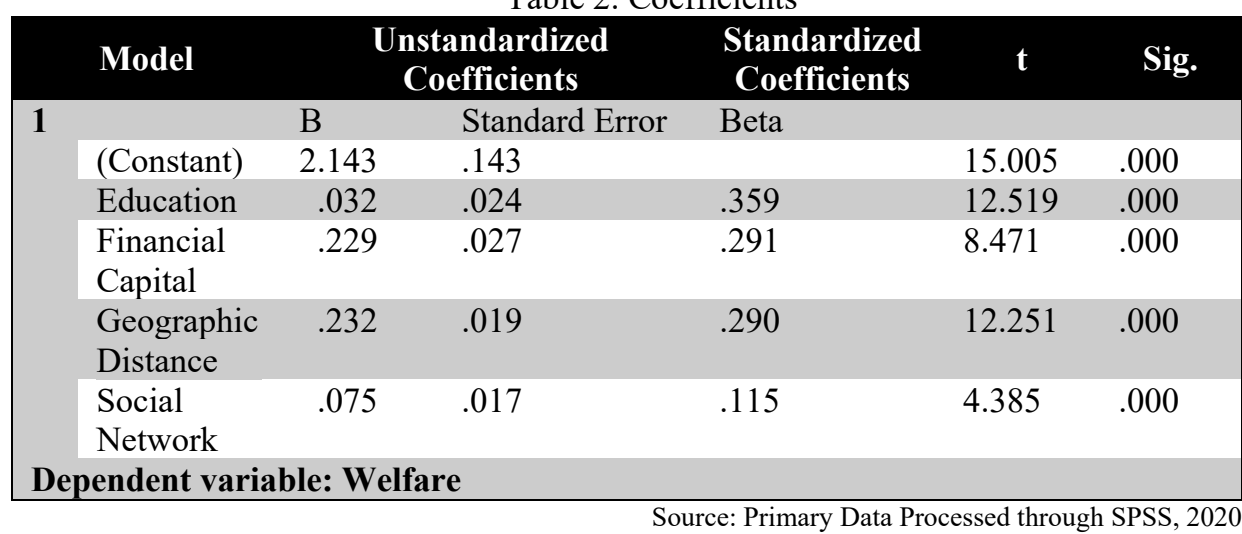

The $t$ value for education (X1) was 12.519 with a significance value of 0.000 , smaller than 0.050 . Therefore, education (X1) partially or individually influences the welfare of the street vendors. The $t$ value for financial capital (X2) was 8.471 with a significance value of 0.00 , smaller than 0.050 . This means that financial capital (X2) partially or individually influences the welfare of the street vendors. 
The $\mathrm{t}$ value for geographical distance (X3) was 12.251 with a significance value of 0.00 , smaller than 0.050 . Therefore, the geographical distance (X3) partially or individually affects street vendors' welfare. The t value for social networks (X4) was 4.385 with a significance value of 0.00 , less than 0.050 , meaning that social networks (X4) partially or individually affect the welfare of street vendors.

In the regression analysis output, the beta value of education was 0.359 while financial capital had 0.291 . Furthermore, the geographical distance beta value was 0.290 , while the social network had 0.115 . Therefore, education (X1) had the highest beta value and significantly influenced the welfare of street vendors.

\section{DISCUSSION}

According to most government officials, street vendors are part of the informal sector that interferes with the beauty of the city (Batréau \& Bonnet, 2015; Racaud et al., 2018). Furthermore, they create unfair competition for more established shop owners and reduce their profits by offering pirated and counterfeit goods (Forkuor et al., 2017). Some governments, such as Bangkok and Thailand, allow street vendors to run their businesses (Kusakabe, 2006). In Bangkok, they have developed as an economic entity and have succeeded in reducing poverty (Nirathron, 2006b).

Urbanization increases land values and economic growth and development (Marzuki \& Jais, 2020). For this reason, most public spaces are occupied by traders, a major problem in developing countries (Brown, 2006). Generally, street vendors use public spaces to trade and market their products and have a significant turnover. In the last ten years, many traders with substantial capital have been realized in cities. The number of small traders continues to surge because their merchandise is often sold quickly.

The potential of street vendors and the entire informal sector cannot be underestimated. For instance, it offers employment opportunities and absorbs the workforce not accommodated in the formal sector (Cuevas et al., 2009; Tichelaar, 2015). The formal sector is pressured to provide decent wages and working conditions, promoting the informal sector (Nazara, 2010). Furthermore, the informal sector makes a positive contribution that enables the formal sector to survive by distributing goods (Mcintyre-mills \& Romm, 2019). It is also a "safety haven" for the unskilled and poorly educated urban residents because it provides alternative sources of income, contributing to their survival.

Most street vendors come from the middle- and lower-class groups of society. During the Covid-19 pandemic, most business people went to the streets to market their products. The Pizza Huts businessmen and several bakers sent marketers to the roadsides to enhance access to buyers. PT. Telekomunikasi Indonesia (Telkom) also sends marketers to the streets to pick potential buyers. 
Eko Handoyo, Tutik Wijayanti

The Factors Affecting the Welfare of Street Vendors in Indonesia

This study showed that education, financial capital, geographical distance, and social networks influence the welfare of street vendors. Therefore, these individuals fight for their welfare because they have an entrepreneurial ethos and unyielding spirit. However, the welfare gains tend to be higher in case the government, through the pro-people policies, provides opportunities for them to run their business. These include issuing regulations that provide room for movement and empowerment as economic entities. The city government should prepare the areas that are accessible to the community for street vendors to trade safely and comfortably.

In case the land in urban areas is no longer usable, the city government should cooperate with investors from the formal sector to allow street vendors to trade in their places. Suppose this is not possible because the city is overcrowded, the government should regulate and organize existing public spaces to be used by the street vendors. This is in line with Roever \& Skinner (2016), which stated that the poor urban residents, specifically street vendors, need to access the public spaces to run their businesses seamlessly. Additionally, government policies favoring street vendors will help to maintain their livelihoods sustainably (Assan \& Chambers, 2014; Milgram, 2011; Patel et al., 2014; Timalsina, 2011; Uwitije, 2016).

\section{CONCLUSIONS}

This study established that street vendors in Semarang city: (1) have low welfare even though they can meet their daily living needs, (2) simultaneously welfare is affected by the education, financial capital, geographical distance, and social network. Therefore, the government should formulate appropriate policies that promote the survival of street vendors. Access to public spaces and institutions that are beneficial for a sustainable future of street vendors should be encouraged. Geographical factors and social networks have a positive effect on the welfare of street vendors, so further and in-depth studies are needed on the influence of geographic factors and social networks on the welfare of street vendors.

\section{ACKNOWLEDGEMENTS}

The authors express gratitude to the Director of the Postgraduate, Universitas Negeri Semarang, for funding the study, and Native Proofreading Service (NPS) for editing the manuscript.

\section{REFERENCES}

Andersen, J. G. (2012). Welfare States and Welfare State Theory (Issue January). https://www.researchgate.net/publication/271217504_Welfare_States_and_Welfare_State Theory

Anggraini, W. (2019). Pengaruh Faktor Modal, Jam Kerja, dan Lama Usaha terhadap Pendapatan Usaha Kecil, Mikro, dan Menengah (Studi Kasus Pedagang Pasar Pagi Perumdam II Sriwijaya Kota Bengkulu. Skripsi. 
Assan, J. K., \& Chambers, T. (2014). India's Street Vendors and The Struggle to Sustain Their Livelihoods and Informal Enterprises: Unionization, Political Action and Sustainable Development. International Journal of Development and Sustainability, 3(January), 2140 2161.

Batréau, Q., \& Bonnet, F. (2015). Managed Informality: Regulating Street Vendors in Bangkok. City and Community, 15(1), 29-43.

Bhowmik, S. K. (2005). Street vendors in Asia: A Review. Economic and Political Weekly, 22562264.

Bromley, R. (1978). Organization, Regulation and Exploitation in the So-Called 'Urban Informal Sector': The Street Traders of Cali, Colombia. World Development, 6(9), 1161-1171.

Bromley, R. (2000). Street Vending and Public Policy: A Global Review. International Journal of Sociology and Social Policy, 20(1), 1-29.

Brown, A. (2006). Contested Space: Street Trading, Public Space, and Livelihoods in Developing Cities. Rugby ITDG Publishing.

Camacho, C., Mariani, F., \& Pensieroso, L. (2017). Illegal immigration and the shadow economy. International Tax and Public Finance, 24(6), 1050-1080. https://doi.org/10.1007/s10797017-9444-5

Creswell, J. W. (2014). Research Design Qualitative, Quantitative, and Mixed Methods Approaches Fourth Edition. SAGE Publications, Inc.

Cuevas, S., Mina, C., Barcenas, M., \& Rosario, A. (2009). Informal employment in Indonesia. In ADB Economics Working Paper Series (Vol. 156). https://doi.org/10.2139/ssrn.1611406

El-Azzazy, M. (2019). Street vending challenges and opportunities: the case of women fish vendors in Fayoum. Thesis. https://core.ac.uk/download/pdf/333723892.pdf

Feige, E. L. (1990). Defining and estimating underground and informal economies: The new institutional economics approach. World Development, 18(7), 989-1002. https://doi.org/10.1016/0305-750X(90)90081-8

Forkuor, J. B., Akuoko, K. O., \& Yeboah, E. H. (2017). Negotiation and Management Strategies of Street Vendors in Developing Countries: A Narrative Review. SAGE Open, January-Ma, 1-13. https://doi.org/10.1177/2158244017691563

Gatere, M. (2016). Factors Influencing Performance of Businesses Run By Women Street Vendors In Ngara Ward, Starehe Sub-County, Kenya. Thesis.

Giraldo, M., Garcia-Tello, L., \& Rayburn, S. W. (2020). Street vending: transformative entrepreneurship for individual and collective well-being. Journal of Services Marketing, 34(6), 757-768. https://doi.org/10.1108/JSM-08-2019-0322

Golubovic, N., \& Dzunic, M. (2015). Social capital as a determinant of the shadow economy in the Republic of Serbia. Ekonomski Horizonti, 17(3), 173-187. https://doi.org/10.5937/ekonhor1503173g

Harahap, E. F. (2017). Analysis of Determinants of Income and Efforts to Improve the Welfare of Street Vendors in Padang City. European Journal of Business and Management, 9(3), 118 124.

Horn, P. (2018). Street Vendor Licensing and Permits - Reflections from StreetNet International. WIEGO. https://www.wiego.org/sites/default/files/publications/files/Horn-WIEGOResource-Document-10.pdf

Ifotania. (2010). Analisis Pengaruh Tingkat Pendidikan, Jam Kerja, dan Jenis Usaha terhadap Pendapatan Pedagang Kaki Lima di kota Surabaya Tahun 2010. Skripsi.

Karondo, J. V, \& Tumaini, U. J. (2021). the Role of Street Food Vending To the Vendor's Household Welfare in Ilala Municipality in Dar Es Salaam, Tanzania. Business Education Journal, I(II), 1-9. https://cbe.ac.tz/bej/index.php/bej/article/view/243

Kebede, G. F. (2015). Social Capital and the Urban Informal Economy: The Case of Street Vendors in Addis Ababa, Ethiopia. Dissertation. https://core.ac.uk/download/pdf/35317531.pdf

Khasnobis, B. G., Kanbur, R., \& Ostrom, E. (eds). (2006). Linking The Formal and Informal Economy Concept and Policies. Oxford University Press. 
Eko Handoyo, Tutik Wijayanti

The Factors Affecting the Welfare of Street Vendors in Indonesia

Kusakabe, K. (2006). Policy Issues on Street Vending: An Overview of Studies in Thailand, Cambodia and Mongolia. International Labour Organization.

Losby, J. L., Else, J. F., Kingslow, M. E., Edgcomb, E. L., Malm, E. T., \& Kao, V. (2002). Informal Economy Literature Review (Issue December). ISED Consulting and Research and The Aspen Institute.

Marliati. (2020). Factors Influencing on Entrepreneurial Behavior of Street Vendors (A Case in Pekanbaru City, Riau Province). AGRARIS: Journal of Agribusiness and Rural Development Research, 6(2). https://doi.org/10.18196/agr.6296

Marzuki, A., \& Jais, A. S. (2020). Urbanisation and the concerns for food security in Malaysia. Planning Malaysia, 18(3), 202-217. https://doi.org/10.21837/PM.V18I13.786

Mcintyre-mills, J., \& Romm, N. R. A. (2019). Democracy and Governance for Resourcing the Commons. Springer. https://doi.org/10.1007/978-3-030-04891-4

Midgley, J. (1999). Social Development the Developmental Perspective in Social Welfare. In SAGE Publications, Ltd. Sage Publications, https://doi.org/10.1017/CBO9781107415324.004

Miles, M. B., Michael, H. A., \& Saldana, J. (2014). Qualitative Data Analysis A Methods Source Book Edition 3. SAGE Publications, Inc.

Milgram, B. L. (2011). Reconfiguring space, mobilizing livelihood: Street vending, legality, and work in the Philippines. Journal of Developing Societies, 27(3-4), 261-293. https://doi.org/10.1177/0169796X1102700403

Mitullah, W. V. (2003). Street Vending in African Cities: A Synthesis of Empirical Findings from Kenya, Cote D'ivoire, Ghana, Zimbabwe, Uganda and South Africa. Background Paper for the 2005 World Revelopment https://openknowledge.worldbank.org/bitstream/handle/10986/9211/WDR2005_0027.pdf ?sequence $=1$

Mramba, N. R. (2015). The Marketing Communication Strategies of Street Vendors in Dar Es Salaam Tanzania the Marketing Communication Strategies of Street Vendors in Dar es Salaam. American Academic \& Scholarly Research Journal, 7(4), 33-44.

Mróz, B. (2018). Shadow economy in a turbulent environment: evidence from Poland. Journal of Money Laundering Control, 21(3), 328-339. https://doi.org/10.1108/JMLC-08-2017-0034

Mukherjee, D. (2016). Informal Economy in Emerging Economies: not a substitute but a compliment. International Journal of Business and Economic Development, 4(3), 16-27.

Nazara, S. (2010). Ekonomi Informal di Indonesia: Ukuran, Komposisi, dan Evolusi. Organisasi Perburuhan Internasional.

Nilakusmawati, D. P. E., Susilawati, M., \& Wall, G. (2019). A Welfare Model of Street Vendors: Cases from Denpasar, Bali, Indonesia. International Journal of Human Resource Studies, 9(3), 1-20.

Nirathron, N. (2006a). Fighting Poverty from the Street A Survey of Street Food Vendors in Bangkok (Issue 1). International Labour Organization. https://staging.ilo.org/wcmsp5/groups/public/---asia/---robangkok/documents/publication/wcms bk pb 128 en.pdf

Nirathron, N. (2006b). Fighting Poverty from the Street A Survey of Street Food Vendors in Bangkok (Issue 1). International Labour Organization.

Nurbaiti, B., \& Chotib, C. (2020). The Impact of Group and Network on Welfare: Finding of Gender Identity in The Urban Informal Sector In East Flood Canal (BKT), Jakarta Proceedings of 3rd International Conference on Strategic and Global Studies, ICSGS 2019, 146-157. https://doi.org/10.4108/eai.6-11-2019.2297265

Patel, K., Guenther, D., Wiebe, K., \& Seburn, R. A. (2014). Promoting food security and livelihoods for urban poor through the informal sector: a case study of street food vendors in Madurai, Tamil Nadu, India. Food Security, 6(6), 861-878. https://doi.org/10.1007/s12571-0140391-z

Petrova, K. (2018). Globalization and the Informal Economy in Developing Countries. In 
Globalization in Developing Countries (Issue July, pp. 1-32). https://www.researchgate.net/search.Search.html?type=researcher\&query=Underground and Informal Economies in Developing Countries

Portes, A., Castells, M., \& Benton, L. A. (eds). (1989). The Informal Economy Studies in Advanced and Less Developed Countries. The John Hopkins University Press.

Racaud, S., Kago, J., \& Owuor, S. (2018). Introduction: Contested Street: Informal Street Vending and its Contradictions. Articulo-Journal of Urban Research, 17(18), 1-16.

Rakhmatulloh, A. R., Buchori, I., Pradoto, W., \& Riyanto, B. (2018). The power of accessibility to land price in Semarang urban corridors, Indonesia. Planning Malaysia, 16(1), 118-129. https://doi.org/10.21837/pmjournal.v16.i5.416

Rei, D. (2008). The Impact of Institutions and Policy on Informal Economy in Developing Countries An econometric exploration (Issue Working Paper No. 84).

Roever, S., \& Skinner, C. (2016). Street vendors and cities Street vendors and cities. Environment and Urbanization, 28(2), 1-16. https://doi.org/10.1177/0956247816653898

Rosales Chavez, J. B., Bruening, M., Ohri-Vachaspati, P., Lee, R. E., \& Jehn, M. (2021). Street food stand availability, density, and distribution across income levels in Mexico City. International Journal of Environmental Research and Public Health, 18(8), 1-17. https://doi.org/10.3390/ijerph18083953

Rothenberg, A. D., Gaduh, A., Burger, N. E., Chazali, C., Tjandraningsih, I., Radikun, R., Sutera C., \& Weilant, S. (2016). Rethinking Indonesia's Informal Sector. World Development, 80 , 96-113. https://doi.org/10.1016/j.worlddev.2015.11.005

Ruzek, W. (2015). The informal economy as a catalyst for sustainability. Sustainability (Switzerland), 7(1), 23-34. https://doi.org/10.3390/su7010023

Setyaningsih, I., Sukiman, S., \& Widyaningsih, N. (2019). The Analysis of Factors Affecting Income Level of Street Vendors. Eko-Regional Jurnal Pengembangan Ekonomi Wilayah, 14(2), 85-93. https://doi.org/10.20884/1.erjpe.2019.14.2.1330

Stuart, E., Samman, E., \& Hunt, A. (2018). Improving the lives of workers at risk of being left behind (Working Paper 530; Issue January).

Syariffuddin, Wahyono, H., \& Brotosunaryo. (2017). Street Vendors Hypergrowth: Consequence of Uncontrolled Urbanization in Semarang City. Komunitas: International Journal of Indonesia Society and Culture, 9(1), 81-91. https://doi.org/10.15294/komunitas.v9i1.8497

Tichelaar, E. (2015). Integrating Jakarta's Street vendors in Architecture. Master Thesis Research.

Timalsina, K. P. (2011). An Urban Informal Economy: Livelihood Opportunity to Poor or Challenges for Urban Governance. Global Journal of Human Social Science, 11(2). https://globaljournals.org/GJHSS_Volume11/4-An-Urban-Informal-Economy.pdf

Utomo, C., Rahmawati, Y., \& Krestawan, I. (2018). Development of Urban Market Spatial for Highest and Best Use of Land Productivity and Sustainability. Planning Malaysia, 16(1), $163-172$.

Uwitije, C. (2016). Contributions of Street Vending on Livelihood of Urban Low-Income Households in the City of Kigali, Rwanda. Thesis. http://erepository.uonbi.ac.ke/handle/11295/97752

Widjajanti, R. (2016). The Space Utilization by Street Vendors Based on the Location Characteristics in the Education Area of Tembalang, Semarang. Procedia - Social and Behavioral Sciences, 227(November 2015), 186-193. https://doi.org/10.1016/j.sbspro.2016.06.061

Winter, B. C. (2017). Reappropriating Public Space in Nanchang, China: A Study of Informal Street Vendors. Dissertation. (Issue July).

Received: $15^{\text {th }}$ August 2021. Accepted: $13^{\text {th }}$ October 2021 